\title{
日本知能情報ファジィ学会誌 総目次
}

第 23 巻 第 1 号 第 6 号 平成 23 年 $2 \cdot 4 \cdot 6 \cdot 8 \cdot 10 \cdot 12$ 月

号 ページ

\section{巻頭言}

進化計算の魅力

小林 重信 11

顔学は関係の学である 原島 博 2125

サービスに科学的・工学的アプローチを 内藤 耕 3267

「想定外」と国民的合意形成 河村 廣 4375

ことばが結ぶもの 松澤 和光 5 663

数理議論学の可能性 新田 克己 6797

\section{挨 拶}

第 12 期会長に就任して

高木 友博 4

376

\section{特 集}

\section{進化計算の新しい展開}

「進化計算の新しい展開」特集にあたって …….................................. 能島 裕介 12 [解説]

遺伝的プログラミングの理論的展開

伊庭 斉志 13

関数最適化のための分布推定アルゴリズム

知的インタラクティブシステムのための最小ユーザフィードバック

「知的インタラクティブシステムのための最小ユーザフィードバック」特集にあたって

[解説]

最小ユーザフィードバックの枠組みとその要素技術

最小ユーザフィードバックのためのインタフェースデザイン

最小ユーザフィードバックに基づく制約付きクラスタリング

\section{顔の情報処理}

$$
\text { 岡部 正幸・山田 誠二 } 1
$$

「顔の情報処理」特集にあたって

\section{[解説］}

顔の情報処理 一顔表情の知覚・認知を中心に渋井進・松峷 直幸・山田 寛 2 サービス・イノベーションと新たな知能情報技術の創出に向けて

「サービス・イノベーションと新たな知能情報技術の創出に向けて」特集にあたって

\section{[解説]}

\section{片桐 英樹・本村 陽一・谷崎 隆士 3268}

サービス工学の概要

蔵田 武志 3269

サービス工学技術戦略マップ 大隈 隆史 3276

サービス工学に打ける大規模データモデリングアプローチ 本村 陽一 3281

感情指向型コンピュータインタラクションシステム 市村 匠・目良 和也 3287

ファジィ確率環境下における多目的最適化 片桐 英樹・坂和 正敏 3294

データ解析コンペティションでの取組みと成果

一運営のための組織体制作り及び産学連携一 中川 慶一郎・生田目 崇 3301 
地方に打ける地域密着型のサービス工学研究

ーサービス工学研究センターでの活動と今後の展望一

谷崎 隆士・加島 智子 ·片岡 隆之 3306

建築・土木分野におけるソフトコンピューティングの応用

「建築・土木分野に挑けるソフトコンピューティングの応用」特集にあたって

堤 和敏 - 秋山 孝正 4

第 15 回曖昧な気持ちに挑むワークショップ選抜論文

「第 15 回曖昧な気持ちに挑むワークショップ選抜論文」特集にあたって

\section{ことばエ学}

本田あ打い 4

591

「ことば工学」特集にあたって

阿部 明典 5664

[解説]

ことば工学とは？

阿部 明典 5666

「物語論の情報学」の実践としての物語生成システム

小方孝 5676

メタファーの話 内海 彰・鍋島 弘治朗 5686

HAL は遥か ? 一笑うコンピュータの過去, 現在と将来 ジェプカラファウ・荒木 健治 5696

コーパスに基づく辞書づくりーこれからの国語辞典はこう変わるー ……… 柏野 和佳子 54705

省エネ・節電に挑むソフトコンピューティング

「省エネ・節電に挑むソフトコンピューティング」特集にあたって

\section{[解説]}

日本知能情報ファジィ学会会誌編集委員会 6

居住者の選好を考慮した省エネ行動選択支援ツール 上野 剛 6

799

非侵入型モニタリングシステム 中野 幸夫 6807

ヒートポンプ式給湯機の沉用運転ルールの生成 ……… 所 健一・小松 秀徳・篠原 靖志 6813

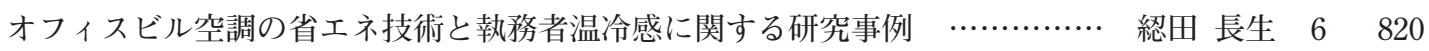

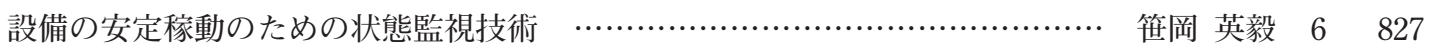

環境目標実現への省 $\mathrm{CO} 2$ ソリューションーコジェネ設備および圧空設備の省エネー

鈴木 康央 6834

\section{解 説}

ニューラルネットワーク最新事情（5）：脳型コンピュータに向けて

萩原 将文 199

統計的データ解析入門 第 2 回: 情報量規準と時系列解析

田村 義保 1107

統計的データ解析入門 第 3 回: 多変量解析概論

田村 義保 2228

RoboCup サッカー3D シミュレーションリーグ解説：仕組みと環境構築

中島 智晴 - 中邨 陽介 3

312

Linux と USB bootable Android 市村 匠・木暮 祐一 3

RoboCup サッカー3D シミュレーションリーグ解説：競技会の概要とエージェント開発 中島 智晴・中邨 陽介・炭谷 剛志 4

ソフトコンピューティングのための Android スマートフォン・インタフェース

SOFT が掲げるマルチコアとは

市村 匠 4

620

RoboCup サッカー 2D シミュレーションリーグ解説：仕組みと環境構築……… 秋山 英久 5

RoboCup サッカー 2D シミュレーションリーグ解説：サンプルエージェントを使ったチーム開発

\section{報 告}

第 15 回曖昧な気持ちに挑むワークショップ開催報告

徳丸 正孝 1 
MDAI2010 参加報告

成川 康男 1

FAN ／iFAN 2010 開催報告

新妻 実保子 1

118

第 9 回人間共生システム研究会参加報告

鈴木 秀和 2235

第 2 回国際察知計算シンポジゥム (ISAC2010) 報告

趙 強福 2237

第 6 回ファジィ学問塾開催報告

関 宏理・大曽根 圭輔 2239

SCIS \& ISIS 2010 開催報告

渡辺 桂吾 3328

第 1 回ソフトコンピューティング研究会 WEB 開催報告

大曽根 圭輔 · 寄田 明宏

633

第 4 回 ポトラック\& ワークショップ参加報告

滝優基 4635

2011 IFSA World Congress - AFSS International Conference（IFSA - AFSS2011）報告

FUZZ - IEEE2011 参加報告

ウィドヤント ラフマット・高間 康史 5

721

第 23 回ソフトコンピューティング若手研究会開催報告

山崎 洋一 5

723

FSS2011 開催報告

豊田 哲也 6845 前田 陽一郎 $6 \quad 847$

\section{書 評}

(社) 電気学会 進化技術応用調査専門委員会 (編)：

「進化技術ハンドブック：第 I 巻 基礎編」……........................... 能島 裕介 $\quad 1 \quad 120$

加藤直樹 (著), 羽室行信 (著), 矢田勝俊 (著) :

「データマイニングとその応用」

高間 康史 2

241

Rolf Pfeifer, Josh Bongard（著）, 細田耕, 石黒章夫（訳）：

「知能の原理一身体性に基づく構成論的アプローチー」……............... 河 正彦 3

Frans de Waal（著）, 柴田裕之（訳）：

「共感の時代へ一動物行動学が教えてくれること一」

片上大輔 4

ウォルター・J・フリーマン (著), 浅野孝雄 (訳), 津田一郎 (校閲) :

「脳はいかにして心を創るのか一神経回路網のカオスが生み出す志向性・意味・自由意志」

阿部重夫 (著) :

大海 悠太 5

725

「パターン認識のためのサポートベクトルマシン入門」

荒井良徳 6

851

\section{用語解説}

実験考古学（Experimental Archaeology）

長井 謙治 1121

ペルソナノシナリオ法

半教師付きクラスタリング（Semi- supervised Clustering）

ペアワイズ分類（Pairwise Classification）

植村 弘洋 1121

神澤 雄智 2242

岡部 正幸 2242

減災

野田 五十樹 3331

事業継続計画：BCP (Business Continuity Plan)

高木 方隆 3331

Bag of features

岡本 一志 4638

拡散テンソル MRI（Diffusion Tensor MRI)

吉田 真一 4638

ゆとりニューラルネットワーク（Affordable Neural Network)

上手 洋子 5726

介護予防

辺見一男 5726

リモートセンシング

浅沼 市男 6852

緊急時迅速放射能影響予測ネットワークシステム（SPEEDI）

岡本 眞一 6852

\section{特集論文}

\section{[原著論文]}

CUDA 環境におけるデータ並列化を用いた遺伝的アルゴリズムの実装手法 
島モデル型多目的 GAにおける可視化を用いたユーザの意思に基づくインタラクティブ探索

2 点嗜好法を適用した複数参加型トーナメント方式を用いた対話型遺伝的アルゴリズム

オフィスビルのファサードを対象としたデザイン発想支援システムの開発

その 1. IED（Interactive Differential Evolution）個体選択パターンの検討

複数許容解探索型粒子群最適化法の無線センサネットワークへの適用

ーフラッディング効率化のための各センサノードの送信電力調整—

顔特徴とコンテキスト情報に基づく人物識別

長島 淳也・宇谷 明秀・山本 尚生 1

山口 純平・嶋田 和孝・榎田 修一・江島 俊朗・遠藤 勉 2

口唇の色彩情報扎よび形状情報に着目した発話フレーム検出法

高橋 毅・景山陽一・西田 眞・若狭 带希奈 2

表情の時系列変化を可視化する表情空間チャート

間所 洋和・佐藤 和人・閒脇 さくら 2

顔特徵量の有用性推定に基づく特徵抽出による表情認識 …………野宮 浩揮・宝珍 輝尚 2

157

表情の変化量と笑いの分類の検討

益子 行弘・萱場 奈津美・辨藤 美穂 2

170

適応的格子法と部分変形法を用いた高速で自然な Multi-level B-spline 変換

表情顔の魅力評価に関わる心理的要因

黒眼の形状と瞬きの変化からの表情認識

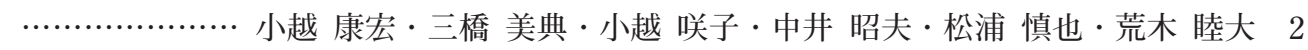

オフィスビルのファサードを対象としたデザイン発想支援システムの開発

IDES (Interactive Differential Evolution with Score) の提案

河野 高英 ·堤 和敏 4

設計者のイメージを満足した大スパン屋根形態の形態創生・

発想支援に関する研究 イメージと力学的合理性の 2 目的評価

曖昧なボロノイ図を利用した曲面分割による形態形成

武田 侑也·堤 和敏 4

Web リソースと地理情報を活用した新店舗情報の自動収集に関する研究

人工社会モデルによる地方都市まちづくり政策に関する考察

SPEA2 を用いた既存学校建築リノベーションの設計支援システムに関する研究

クラシファイアシステムを用いた集合住宅の減築シミュレーション

一獲得したルールと形態に関する考察—……… 山邊 友一郎・有吉 智彦・谷 明勲 4

住宅構造部材の転用及び循環システムに関する基礎的研究

GAによる実用化を目指した長期的な橋梁維持管理計画策定

堀 駿・林 将利 $\cdot$ 永井 拓生 $\cdot$ 新谷 眞人 4

………………中津 功一朗・古田 均 · 野村 泰稔・高橋 亭輔·石橋 健 · 三好紀晶 4

ライフライン網の相互連関を考慮した災害復旧計画問題に関する研究

味方 さやか・小林一郎 4

都市高速道路の知識利用型ファジィ流入制御に関する適用性の検証

Actor-Critic アルゴリズムによる感覚尺度を学習する照明制御システム 
距離画像センサを用いた人物の流動情報計測に関する研究

安彦 智史・田中 成典・村本 晋一・上谷 弘平・若林 克磨 4

移動体除去した平面パノラマ画像の自動生成に関する研究

-最適な背景画像の推定方法- ………谷口 寿俊 - 西田 義人 · 田中 成典 · 加藤 雄大 4

背景補完した全周パノラマ画像の自動生成に関する研究

一領域抽出による移動体除去方法一

西田 義人 ·田中 成典・谷口 寿俊・加藤 雄大 4

SXF データから拡張 DM データへの変換技術の研究開発

田中 成典・今井 龍一・樫山 武浩・渡辺 完弥 4

555

点群座標データを用いた 3 次元モデルの自動生成に関する研究

田中 成典 · 今井 龍一・中村 健二 ・ 川野 浩平 4572

ベクトル值型ショケ積分モデルー集合関数間の関係を考慮した性質一 $\cdots \cdots \cdots$ 高萩 栄一郎 44596

複数の順位情報に基づく評価関数の推定

福田 亮治・岡 薰 4

604

[ショートノート $]$

共単調加法的汎関数の Riesz 型積分表示定理

河邊 淳・相馬 匡博 4

592

\section{一般論文}

[原著論文]

神経振動子場に打ける局在振動の位相同期に関する研究

宮田 龍太・伊達 章・倉田 耕治 22243

多数のパラメータを用いるファジィ $c$ 平均識別器の訓練データ数による性能比較

市橋 秀友・本多 克宏・野津 亮 2

$\mathrm{H} \infty$ Output Feedback Control for A Class of General Fuzzy Systems

Shusaku NISHIKAWA · Jun YONEYAMA 3

取引形態を考慮した地域冷暖房プラントの多目的運転計画に対する

対話型ファジィ満足化手法 ………………..... 坂和 正敏・松井 猛・石丸 恵一 3

2 レベル非線形計画問題に対する Particle Swarm Optimization に基づく

Stackelberg 解の計算方法 松井 猛・坂和 正敏・石丸 恵一 3

多目的確率線形計画問題に対するファジィアプローチ 矢野 均 3

テキストの主題に基づく一貫性評価と結論抽出への応用 砂山 渡・谷川 信弘 5

検索エンジンを用いた関連語の自動抽出

渡部 啓吾・Danushka BOLLEGALA ·松尾 豊・石塚 満 5

生体表現システム：ファジィインタフェースを用いた培養神経回路網と

ロボットとの相互接合 ………… 林 勲・徳田 農・清原 藍・田口 隆久·工藤 卓 5 類似度に基づき成長する複雑ネットワーク生成モデルの提案

ファジィ $c$-平均識別器の訓練時間の改善 市橋 秀友・本多 克宏・野津 亮 5

SVM を用いた対話的文書検索における適合性評価の比較分析

動詞教示インタラクションを通じたロボットに対する親和的心理の構築

[実践研究論文]

長谷川大·荒木 健治 6

863

SENSITIVITY - BASED INFORMATION SELECTION FOR PREDICTING INDIVIDUAL'S

SUB - HEALTH ON TCM DOCTORS' DIAGNOSIS DATA

Yi WANG $\cdot$ Ying DAI $\cdot$ Feng GUO $\cdot$ Shaozi LI 5

[ショートノート]

時空間情報と動作に基づく認証方法

… 角田 雅照 - 伏田 享平 · 亀井 靖高 - 中村 匡秀 · 三井 康平 - 後藤 慶多 - 松本 健一 6 